\title{
White-rot fungi capable of decolourising textile dyes under alkaline conditions
}

\author{
Cristiane A. Ottoni • Cledir Santos • Zofia Kozakiewicz • Nelson Lima
}

Received: 22 December 2011 / Accepted: 6 September 2012 /Published online: 25 September 2012

(C) Institute of Microbiology, Academy of Sciences of the Czech Republic, v.v.i. 2012

\begin{abstract}
Twelve white-rot fungal strains belonging to seven different species were screened on plates under alkaline condition to study the decolourisation of the textile dyes Reactive Black 5 and Poly R-478. Three strains of Trametes versicolor (Micoteca da Universidade do Minho (MUM) 94.04, 04.100 and 04.101) and one strain of Phanerochaete chrysosporium (MUM 94.15) showed better decolourisation results. These four strains were used for decolourisation studies in liquid culture medium. All four selected strains presented more efficient decolourisation rates on Reactive Black 5 than on Poly R-478. For both dyes on solid and liquid culture media, the decolourisation capability exhibited by these strains depended on dye concentration and $\mathrm{pH}$ values of the media. Finally, the decolourisation of Reactive Black 5 by $T$. versicolor strains MUM 94.04 and 04.100 reached $100 \%$. In addition, the highest white-rot fungi ligninolytic enzyme activities were found for these two strains.
\end{abstract}

\section{Introduction}

Water is a rare and precious commodity, and only an infinitesimal part of the water reserves in the earth (ca. $0.03 \%$ ) constitutes the resource that is available for human activities. The growth of the world population and industry has given rise to a constantly growing demand for water compared to the available supply which remains constant (Prigione et al. 2008).

Worldwide, over 10,000 different dyes and pigments are used in dyeing and printing manufacture (Revankar and Lele 2007). Some of the industries involved with textile, paper,

C. A. Ottoni $\cdot$ C. Santos $\cdot$ Z. Kozakiewicz $\cdot$ N. Lima $(\bowtie)$

IBB - Institute for Biotechnology and Bioengineering,

Centre of Biological Engineering, University of Minho,

Campus de Gualtar,

4710-057 Braga, Portugal

e-mail: nelson@ie.uminho.pt carpet, leather and printing manufacture are responsible for dye and other chemical compounds released into river and other natural water sources as wastewater (Aravind et al. 2010). These industrial effluents constitute the major source of water pollution and contain different kind of toxic chemical compounds. Furthermore, toxic and mutagenic effects of these compounds can affect the biodiversity (Novotný et al. 2006; Moya et al. 2010). The volumes discharged, effluent composition and wastewater are generated by the textile industry that is ranked as one of the most polluting among industries' effluents (Reid 1996).

Real textile dye effluents contain dyes and also salts. Sometimes, these salts are present in very high concentrations and ionic strength. These effluents present a neutral to alkaline $\mathrm{pH}$ value (7.0-11.0) with presence of chelating agents, by-products, surfactants, etc. (Faraco et al. 2009). Moreover, most of the wastewater from textile industries has high biological oxygen demand, chemical oxygen demand and total dissolved solids (Kaushik and Malik 2009). Besides being anaesthetic, these effluents can also be mutagenic and carcinogenic (Yesilada et al. 2010).

Since decolourisation is a challenge for the textile industry as well as for wastewater treatment companies, the literature suggests that there is a great potential for developing microbiological decolourisation systems with total colour removal, in some cases within a few hours (Ramya et al. 2007). In the last two decades, white-rot fungi (WRF) have received much attention in this field because of their ability to degrade xenobiotic compounds. Due to their extracellular non-specific free radical-based ligninolytic systems, WRF are able to produce one or more extracellular lignin-modifying enzymes which completely eliminate a variety of xenobiotics, including synthetic dyes, giving rise to non-toxic compounds (Asgher et al. 2009).

The main components of WRF ligninolytic systems are lignin peroxidases (LiP, EC 1.11.1.14), manganese peroxidases 
(MnP, EC 1.11.1.13) and laccases (Lcc, EC 1.10.3.2) (Barrasa et al. 2009; Enayatzamir et al. 2009). Novel enzymes mediated by different secondary metabolites have been described and the non-specific nature of the ligninolytic enzymes makes WRF suitable for treating dye effluents (Toh et al. 2003).

Published studies to date have focused their attention on microbial decolourisation only taking into consideration acidic $\mathrm{pH}$ in wastewater from textile industries. Beside this, Anastasi et al. $(2010 ; 2011)$ also addressed the alkaline conditions when studying simulated and real textile wastewater treatments using Bjerkandera adusta. Trametes sp., Trametes versicolor, Trametes trogii and Irpex lacteus were also studied under alkaline conditions by Maalej-Kammoun et al. (2009), Sukumar et al. (2009), Mechichi et al. (2006) and Kalpana et al. (2011), respectively. Due to the lack of comprehensive studies related with performance of fungal decolourisation close to the alkaline textile effluents, in this study, a screening to obtain WRF that possess the ability to decolourise textile dyes under alkaline conditions and the level of decolourisation are presented.

\section{Materials and methods}

Dye selection

On account of their extensive use in dyeing processes around the world, two dyes were selected namely, diazo Reactive Black 5 (RB5) and anthraquinone Poly R-478 (PR478) (Fig. 1). The dyes were obtained from Sigma-Aldrich (Germany).

\section{Microorganisms}

Twelve strains of WRF, T. versicolor (Micoteca da Universidade do Minho (MUM) 94.04; 04.100; 04.101; 04.104 and 04.105), Pleurotus ostreatus (MUM 94.08), Phanerochaete chrysosporium (MUM 94.15 ( $\approx$ ATCC 24725) and 95.01), I. lacteus (MUM 98.04), B. adusta (MUM 99.04), Fomes fomentarius (MUM 04.102) and Ganoderma applanatum
(MUM 04.103) obtained from the MUM (Braga, Portugal) culture collection, were screened to evaluate their potential for decolourisation of the selected dyes. The continued viability of these strains was monitored on tap water agar cellulose plates (TWA-cellulose, agar $15 \mathrm{~g} / \mathrm{L}$ in tap water with a strip of cellulose paper) and malt extract agar $(20 \mathrm{~g} / \mathrm{L}$ malt extract, $20 \mathrm{~g} / \mathrm{L}$ glucose monohydrate, $1 \mathrm{~g} / \mathrm{L}$ bacto peptone and $15 \mathrm{~g} / \mathrm{L}$ agar) at $4{ }^{\circ} \mathrm{C}$. These were replaced on a monthly basis.

\section{Media}

Liquid culture medium (LCM, sucrose $5.0 \mathrm{~g} / \mathrm{L}$, ammonium sulphate $0.5 \mathrm{~g} / \mathrm{L}$, yeast nitrogen base (YNB) without amino acids and ammonium sulphate $1.7 \mathrm{~g} / \mathrm{L}$ and L-asparagine $1.0 \mathrm{~g} / \mathrm{L}$ ) and each one of the dyes $0.1 \mathrm{~g} / \mathrm{L}$ was used in all decolourisation assays. The stock solutions of the dyes $(100 \times)$, YNB $(10 \times)$ and L-asparagine $(10 \times)$ were filter sterilised using $0.45 \mu \mathrm{m}$ membranes. TWA (agar $15 \mathrm{~g} / \mathrm{L}$ in tap water) was the pre-growth medium used to test the viability of the inocula. The pre-adaption medium (PAM) was LCM containing $0.1 \mathrm{~g} / \mathrm{L}$ of each dye and agar $15 \mathrm{~g} / \mathrm{L}$ for the solidification of the final suspension. Additionally, TWA-cellulose was used as an inducer medium for the white-rot enzyme system of the fungi. For LCM, the initial $\mathrm{pH}$ value was adjusted using $1 \mathrm{~mol} / \mathrm{L} \mathrm{NaOH}$ in a range from 8 to 10 with intervals of 0.5 .

\section{Culture conditions}

An 8-mm diameter plug was cut with a sterile cork borer from the periphery of a 7-day-old colony of TWA-cellulose and inoculated at the centre of a PAM plate. Plates were incubated for 7 days at $30{ }^{\circ} \mathrm{C}$. Then, five plugs of $8 \mathrm{~mm}$ from these cultures were used for the final assays. The final liquid cultures were incubated in $250-\mathrm{mL}$ capacity flasks on a Certomat rotary shaker at $30{ }^{\circ} \mathrm{C}$ and $150 \mathrm{rpm}$. Controls were carried out also under the conditions presented above. In order to compare the variation of biomass and dye concentrations, the controls were carried out under identical condition, but without dyes and inoculum free.
Fig. 1 Chemical structure of dyes used in this study: a RB5 and b Poly R-478

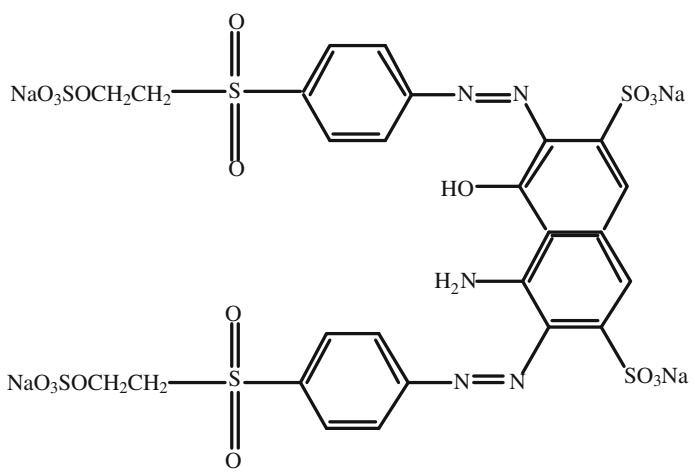

(A)<smiles>CNC(CC(C)(C)C)CC(C)(C)CC(C)Nc1ccc2[nH]c(=O)c(C)c3c2c1C(=O)c1ccccc1-3</smiles>

(B) 
Dead fungal controls were prepared with fungal culture inocula inactivated by autoclaving. Autoclaved biomasses were also included in order to follow the possible contribution of dye adsorption by fungal cell walls. Final results represent at least two independent assays.

Dye, biomass and sucrose determinations

Concentrations of dyes were determined by UV-visible spectrophotometry technique using a decrease in absorption intensity at the maximum wavelength $\left(\lambda_{\max }\right)$ of each dye. Both dyes were scanned from 190 to $900 \mathrm{~nm}$, using a spectrophotometer UV/VIS Jasco V-560. The absorbance value of the LCM containing the initial concentration of each dye corresponds to $100 \%$ of dye. The spectra were obtained from $5 \mathrm{~mL}$ supernatant samples. Biomass concentration was determined by dry weight measurement after drying fungal cells at $105{ }^{\circ} \mathrm{C}$ for $24 \mathrm{~h}$ on a $0.45-\mu \mathrm{m}$ preweighted membrane.

Sucrose concentrations were monitored by highperformance liquid chromatography Jasco AS-950. The detector used was a refractive index (Jasco RI-830). The column used was a MetaCarb $67 \mathrm{H}(300 \times 6.5 \mathrm{~mm})$ and its internal temperature was adjusted to $60{ }^{\circ} \mathrm{C}$. The column mobile phase was $0.005 \mathrm{~mol} / \mathrm{L} \mathrm{H}_{2} \mathrm{SO}_{4}$ aqueous solution at a flow rate of $0.7 \mathrm{~mL} / \mathrm{min}$. Injections of $20 \mu \mathrm{L}$ were performed in an injector with a loop of $30 \mu \mathrm{L}$ capacity.

In order to get the sucrose concentrations, a standard curve was constructed and the initial sucrose concentration in LCM corresponds to $100 \%$. All samples analysed were collected and monitored after 1, 3, 5 and 7 days, respectively. During all processes, $\mathrm{pH}$ values were recorded for each sample.

\section{Enzyme assays}

The enzyme activities of $\operatorname{LiP}\left(\varepsilon_{310 \mathrm{~nm}}=9,300 \mathrm{~L} / \mathrm{mol} / \mathrm{cm}\right)$, $\operatorname{Lcc}\left(\varepsilon_{525 \mathrm{~nm}}=65,000 \mathrm{~L} / \mathrm{mol} / \mathrm{cm}\right), \mathrm{MnP}\left(\varepsilon_{590 \mathrm{~nm}}=53,000 \mathrm{~L} /\right.$ $\mathrm{mol} / \mathrm{cm})$, glyoxal oxidase (GLOX) $\left(\varepsilon_{436} \mathrm{~nm}=18,000 \mathrm{~L} / \mathrm{mol} /\right.$ $\mathrm{cm})$ and proteases $\left(\varepsilon_{440 \mathrm{~nm}}=4,600 \mathrm{~L} / \mathrm{mol} / \mathrm{cm}\right)$ were determinated as previously described by Martins et al. (2003).

For each enzyme activity assay, the same reaction mixtures containing boiled supernatant samples were employed as a blank. One unit (U) of enzyme activity was defined as the amount of the enzyme responsible to change absorbance of $0.01 \mathrm{~min}^{-1}$ under the assay conditions. Enzyme activities of all the samples were expressed as units per litre $(\mathrm{U} / \mathrm{L})$.

\section{Results and discussion}

The ability of the 12 WRF to decolourise two synthetic dyes used in the textile industries, RB5 and PR478, was evaluated. In order to establish the most efficient strains to decolourise both dyes, optimal dye concentration on solid medium (without $\mathrm{pH}$ adjustment) was assessed. At the beginning of each assay, the $\mathrm{pH}$ of the solid media was 5.45 for RB5 and 6.74 for PR478. In addition, the performance of each strain on four different alkaline $\mathrm{pH}$ values, 8.0, 9.0, 10.0 and 12.0, also on solid medium was evaluated. Then, the capability of the most efficient strains to degrade RB5 and PR478 was evaluated on LCM at a pH range from 8.0 to 10.0 within intervals of 0.5 .

Table 1 shows the concentration effect of RB5 on fungal dye degradation on solid medium at $30{ }^{\circ} \mathrm{C}$. For all strains evaluated, RB5 decolourised only at a concentration equal or below $0.1 \mathrm{~g} / \mathrm{L}$. The best results for this dye decolourisation were obtained at $0.05 \mathrm{~g} / \mathrm{L}$ (Table 1). However, for the more stringent concentration $(0.1 \mathrm{~g} / \mathrm{L})$, the best strains decolourising RB5 were: MUM 94.04 and 04.100. Under these conditions, these two strains totally decolourised RB5. The strain MUM 04.101 was the next strain with the highest capability to decolourise RB5. It presented a radial decolourisation rate of $100 \%$ and a very high intensity decolourisation level. The remaining strains do not present degradative capability for RB5 at $0.1 \mathrm{~g} / \mathrm{L}$ on agar plate. In addition, for all RB5 concentrations, the process of dye removal started very early even with the highest dye concentration.

Results obtained for the concentration effect of PR478 (Table 1) on the fungal dye degradation agreed generally with those presented above for RB5 assays. The best degradation performances were also achieved for MUM 94.04 and 04.100, with total decolourisation of PR478. Again MUM 04.101 was the next strain with the highest capability to decolourise PR478 (100 \%) and a very high decolourisation intensity level. For all PR478 concentrations, the process of dye removal started very early even with the highest dye concentration. In contrast, for all RB5 concentrations, the initial degradation rate was slower than those observed for PR478. However, at the end of the processes, RB5 degradation was faster than PR478.

Table 2 shows the $\mathrm{pH}$ effect on fungal dye decolourisation in a pH range between 8.0 and 10.0 at $30{ }^{\circ} \mathrm{C}$ for each dye on solid medium at a dye concentration of $0.1 \mathrm{~g} / \mathrm{L}$. In this study, assays at $\mathrm{pH} 12$ were also performed. However, all fungi lost their viability at this condition of extreme alkaline medium. For the 12 strains evaluated on RB5 at pH8.0, the results indicate that MUM 94.04 and 04.100 were the most efficient ones as they completely decolourised the dye on agar plate by days 8 and 9, respectively. Furthermore, MUM 94.04 and 04.100 were followed by MUM 94.15 and MUM 04.101 which took 14 days to achieve ca. $89 \%$ radial decolourisation rate with a medium intensity level of decolourisation.

At pH9.0 and pH10.0, MUM 94.04 and 04.100 presented the best degradative performance for RB5 once they completely decolourised this dye. These two strains were followed by MUM 94.15 and 04.101, with a radial 
Table 1 Effect of RB5 and Poly R-478 concentration on the dye removal: tests on solid medium for the strain selection

\begin{tabular}{|c|c|c|c|c|c|c|c|c|c|c|c|c|c|c|c|c|c|c|c|c|c|c|c|c|}
\hline \multirow{4}{*}{$\begin{array}{l}\text { MUM } \\
\text { strains }\end{array}$} & \multicolumn{12}{|c|}{ RB5 } & \multicolumn{12}{|c|}{ Poly R-478 } \\
\hline & \multicolumn{4}{|l|}{$A$} & \multicolumn{4}{|l|}{$B$} & \multicolumn{4}{|l|}{$C$} & \multicolumn{4}{|l|}{$A$} & \multicolumn{4}{|l|}{$B$} & \multicolumn{4}{|l|}{$C$} \\
\hline & \multicolumn{4}{|c|}{$0.05 \mathrm{~g} / \mathrm{L}$} & \multicolumn{4}{|c|}{$0.10 \mathrm{~g} / \mathrm{L}$} & \multicolumn{4}{|c|}{$0.15 \mathrm{~g} / \mathrm{L}$} & \multicolumn{4}{|c|}{$0.05 \mathrm{~g} / \mathrm{L}$} & \multicolumn{4}{|c|}{$0.10 \mathrm{~g} / \mathrm{L}$} & \multicolumn{4}{|c|}{$0.15 \mathrm{~g} / \mathrm{L}$} \\
\hline & 1 & 2 & 3 & 4 & 1 & 2 & 3 & 4 & 1 & 2 & 3 & 4 & 1 & 2 & 3 & 4 & 1 & 2 & 3 & 4 & 1 & 2 & 3 & 4 \\
\hline 94.04 & 90 & 90 & ++++ & 5 & 90 & 90 & ++++ & 7 & 90 & 90 & + & 11 & 90 & 90 & ++++ & 9 & 90 & 90 & ++++ & 7 & 90 & 90 & + & 13 \\
\hline 94.08 & 90 & 90 & ++++ & 9 & 90 & 90 & ++ & 13 & 90 & 90 & + & 9 & 90 & 90 & ++ & 12 & 90 & 90 & ++ & 14 & 60 & 80 & + & 12 \\
\hline 94.15 & 90 & 90 & +++ & 8 & 50 & 70 & + & 12 & 60 & 70 & + & 8 & 90 & 90 & ++ & 13 & 90 & 90 & ++ & 12 & 90 & 90 & + & 14 \\
\hline 95.01 & 90 & 90 & ++ & 8 & - & - & - & - & - & - & - & - & 85 & 90 & + & 10 & 75 & - & - & 14 & 55 & - & - & - \\
\hline 98.04 & 90 & 90 & + & 12 & 90 & 90 & + & 12 & 50 & 70 & + & 14 & 90 & 90 & + & 14 & 90 & 90 & + & 9 & 35 & 65 & + & 14 \\
\hline 99.04 & 60 & 80 & + & 11 & 40 & - & - & - & - & - & - & - & 70 & 85 & ++ & 10 & 50 & 70 & + & 14 & 25 & - & - & - \\
\hline 04.100 & 90 & 90 & ++++ & 7 & 90 & 90 & ++++ & 7 & 90 & 90 & + & 12 & 90 & 90 & ++++ & 7 & 90 & 90 & ++++ & 7 & 30 & 50 & + & 14 \\
\hline 04.101 & 90 & 90 & +++ & 10 & 90 & 90 & +++ & 10 & 90 & 90 & + & 14 & 90 & 90 & ++++ & 9 & 70 & 90 & +++ & 12 & 80 & 90 & + & 14 \\
\hline 04.102 & 80 & 90 & ++ & 9 & 50 & - & - & - & - & - & - & - & 75 & 85 & + & 14 & 60 & - & - & 14 & 65 & 70 & + & 12 \\
\hline 04.103 & 40 & 60 & + & 14 & 20 & - & - & - & - & - & - & - & 80 & 90 & + & 12 & 30 & - & - & 14 & 80 & - & - & - \\
\hline 04.104 & - & - & - & - & - & - & - & - & - & - & - & - & 90 & 90 & ++ & 14 & - & - & - & - & - & - & - & - \\
\hline 04.105 & 80 & 90 & ++ & 10 & 50 & 60 & + & 14 & 50 & - & - & - & 85 & 90 & ++ & 14 & 70 & 90 & ++ & 14 & 80 & 90 & + & 14 \\
\hline
\end{tabular}

Diameter of Petri dishes, 90 mm; initial medium pH5.45 (RB5), pH6.74 (Poly-R478)

1 diameter growth rate (in millimetre), 2 diameter decolourisation (in millimetre), 3 relative intensity of decolourisation (between - and ++++ , where, -: null; +: ca. $25 \%$; ++: ca. $50 \%$; +++: ca. $75 \%$; and ++++: ca. $100 \%$ of decolourisation), 4 growth time in days, $A, B, C$ dye concentration

decolourisation rate of ca. 72 and $61 \%$, respectively, and low intensity levels of RB5 decolourisation.
For PR478 (Table 2), the results achieved were also promissory agreeing in general to those presented above

Table 2 pH effect on RB5 and Poly R-478 decolourisations: tests on solid medium for the strain selection

Dyes

\begin{tabular}{|c|c|c|c|c|c|c|c|c|c|c|c|c|c|c|c|c|c|c|}
\hline \multirow[t]{3}{*}{ MUM strains } & \multicolumn{9}{|c|}{ RB5 } & \multicolumn{9}{|c|}{ Poly R-478 } \\
\hline & \multicolumn{3}{|c|}{ pH 8.0} & \multicolumn{3}{|c|}{ pH9.0 } & \multicolumn{3}{|c|}{ pH 10.0} & \multicolumn{3}{|c|}{ pH 8.0} & \multicolumn{3}{|c|}{ pH9.0 } & \multicolumn{3}{|c|}{$\mathrm{pH} 10.0$} \\
\hline & 1 & 2 & 3 & 1 & 2 & 3 & 1 & 2 & 3 & 1 & 2 & 3 & 1 & 2 & 3 & 1 & 2 & 3 \\
\hline 94.04 & 90 & 90 & ++++ & 90 & 90 & ++++ & 90 & 90 & ++++ & 70 & 90 & +++ & 70 & 80 & ++ & 50 & 75 & ++ \\
\hline 94.08 & 60 & - & - & 50 & - & - & 50 & - & - & 55 & 80 & + & 30 & - & - & - & - & - \\
\hline 94.15 & 70 & 80 & ++ & 60 & 65 & + & 30 & - & - & 40 & 55 & + & 20 & 30 & + & - & - & - \\
\hline 95.01 & 50 & - & - & 30 & - & - & - & - & - & 20 & - & - & - & - & - & - & - & - \\
\hline 98.04 & 60 & 70 & + & 60 & - & - & 20 & - & - & 40 & - & - & - & - & - & - & - & - \\
\hline 99.04 & 30 & 50 & + & 30 & - & - & - & - & - & 20 & - & - & - & - & - & - & - & - \\
\hline 04.100 & 90 & 90 & ++++ & 90 & 90 & ++++ & 90 & 90 & ++++ & 90 & 90 & +++ & 70 & 80 & ++ & 70 & 80 & + \\
\hline 04.101 & 60 & 80 & ++ & 40 & 55 & + & 60 & - & - & 60 & 80 & ++ & 45 & 60 & + & 30 & 50 & + \\
\hline 04.102 & 40 & - & - & 20 & - & - & - & - & - & 50 & - & - & 15 & - & - & - & - & - \\
\hline 04.103 & 10 & - & - & - & - & - & - & - & - & - & - & - & - & - & - & - & - & - \\
\hline 04.104 & - & - & - & - & - & - & - & - & - & - & - & - & - & - & - & - & - & - \\
\hline 04.105 & 50 & - & - & 10 & - & - & - & - & - & 20 & - & - & - & - & - & - & - & - \\
\hline
\end{tabular}

Dye concentration, $0.1 \mathrm{~g} / \mathrm{L}$; diameter of Petri dishes, $90 \mathrm{~mm}$; growth time, 14 days

1 diameter growth rate (in millimetre), 2 diameter decolourisation (in millimetre), 3 relative intensity of decolourisation (between - and ++++ , where, -: null; +: ca. $25 \%$; ++: ca. $50 \%$; +++: ca. $75 \%$; and ++++: ca. $100 \%$ of decolourisation) 
for RB5. In addition, at the biodegradation point of view, the PR478 seems to be more recalcitrant than RB5. The hard degradative capability of this dye was also described by Rigas and Dritsa (2006). As observed for RB5, the best strains degrading PR478 on solid medium at $\mathrm{pH} 8.0$ were again MUM 94.04 and 04.100. These two strains presented a radial decolourisation rate of $100 \%$ with a very high intensity of decolourisation after 9 days. Strains MUM 04.101 and 94.08 achieved ca. $89 \%$ radial decolourisation rate with a medium and low intensity, respectively, after 14 days. Finally, MUM 94.15 was the last one with degradative capability at $\mathrm{pH} 8.0$. This strain showed ca. $61 \%$ of radial decolourisation rate with low intensity after 14 days.

At $\mathrm{pH} 9.0$, the best strains degrading PR478 were again MUM 94.04 and 04.100. These two strains achieved ca. $89 \%$ radial decolourisation rate with a medium intensity level of decolourisation after 14 days. MUM 04.101 and 94.15 were the next strains with high capability to degrade this dye. They achieved ca. 67 and $33 \%$ radial decolourisation rate, respectively, with a low intensity level of decolourisation after 14 days.

Finally, at $\mathrm{pH} 10.0$, the best strain to degrade PR478 was MUM 94.04 with ca. $83 \%$ radial growth rate on agar plate with a medium intensity level of decolourisation after 14 days. Additionally, MUM 04.100 and 04.101 presented ca. 89 and $56 \%$ radial growth rate, respectively, with medium intensity level of decolourisation.
Combining the results obtained from the solid medium screening, it was possible to select the best strains to degrade both RB5 and PR478 and to setup dye concentrations and the optimal alkaline pH values. Strains MUM 94.04, 04.100 and 04.101 were selected since they presented the best performance across almost all tests. Moreover, MUM 94.15 was selected since it is the international requested standard used for this kind of test and it was the fourth best strain degrading both dyes on solid medium. These strains were then used for the dye biodegradation in LCM assays with a dye concentration of $0.1 \mathrm{~g} / \mathrm{L}$ at a $\mathrm{pH}$ range from 8.0 to 10.0 within intervals of 0.5 . For both dyes, the decolourisation processes took from 1 to 7 days at $30^{\circ} \mathrm{C}$ and $150 \mathrm{rpm}$.

The decolourisation of each dye under LCM was dependent on the fungal strain and also on the $\mathrm{pH}$ value involved in each process. Additionally, the best $\mathrm{pH}$ values for the decolourisation of RB5 and PR478 were 9.5 for RB5 and 8.5 for PR478 (data not shown). For the dye RB5 (Table 3), the strains MUM 94.04 and 04.100 presented a decolourisation rate of $100 \%$, while strains MUM 04.101 and 94.15 presented rates over $75 \%$. For the dye PR478, strains MUM 94.15, 94.04 and 04.100 presented decolourisation rates of 85,75 and $75 \%$, respectively. On the other hand, MUM 04.101 was not a good PR478 degrader when compared with the other evaluated strains. For both dyes, during the assays, sucrose was totally consumed by all the analysed fungal strains between days 1 and 3 of incubation. Furthermore, the decreasing

Table 3 Profile of WRF selected for dye decolourisation

\begin{tabular}{|c|c|c|c|c|c|c|c|c|c|c|c|}
\hline \multirow[t]{3}{*}{ MUM strains } & \multirow{2}{*}{\multicolumn{6}{|c|}{$\begin{array}{l}\text { RB5 } \\
\text { pH9.5 }\end{array}$}} & \multirow{2}{*}{\multicolumn{5}{|c|}{$\begin{array}{l}\text { Poly R-478 } \\
\text { pH8.5 }\end{array}$}} \\
\hline & & & & & & & & & & & \\
\hline & $\begin{array}{l}\text { Time } \\
\text { (days) }\end{array}$ & $\begin{array}{l}\text { Residual dye } \\
(\%)\end{array}$ & $\begin{array}{l}\mathrm{pH} \\
\text { (final) }\end{array}$ & $\begin{array}{l}\text { Biomass } \\
(\mathrm{g} / \mathrm{L})\end{array}$ & $\begin{array}{l}\mathrm{Lcc} \\
(\mathrm{U} / \mathrm{L})\end{array}$ & $\begin{array}{l}\mathrm{LiP} \\
(\mathrm{U} / \mathrm{L})\end{array}$ & $\begin{array}{l}\text { Residual dye } \\
(\%)\end{array}$ & $\begin{array}{l}\mathrm{pH} \\
\text { (final) }\end{array}$ & $\begin{array}{l}\text { Biomass } \\
(\mathrm{g} / \mathrm{L})\end{array}$ & $\begin{array}{l}\mathrm{Lcc} \\
(\mathrm{U} / \mathrm{L})\end{array}$ & $\begin{array}{l}\mathrm{LiP} \\
(\mathrm{U} / \mathrm{L})\end{array}$ \\
\hline \multirow[t]{4}{*}{94.04} & 1 & 80 & 7.97 & 0.16 & 9.4 & & 95 & 7.43 & 0.17 & & \\
\hline & 3 & 60 & 5.44 & 1.85 & 42.1 & 5.3 & 75 & 5.21 & 0.82 & 20.1 & 6.3 \\
\hline & 5 & 15 & 4.35 & 2.41 & 47.3 & 8.4 & 50 & 4.33 & 1.28 & 30.3 & 13.3 \\
\hline & 7 & 0 & 4.22 & 2.50 & 27.5 & 4.2 & 25 & 4.27 & 1.30 & 26.5 & 20.2 \\
\hline \multirow[t]{4}{*}{94.15} & 1 & 90 & 7.23 & 0.20 & & & 85 & 6.59 & 0.25 & & \\
\hline & 3 & 70 & 6.23 & 1.72 & & 4.3 & 35 & 5.14 & 1.52 & & 4.0 \\
\hline & 5 & 25 & 6.06 & 2.62 & & 7.7 & 25 & 4.23 & 1.71 & & 6.3 \\
\hline & 7 & 25 & 5.15 & 2.67 & & 15.2 & 15 & 4.02 & 1.78 & & 12.7 \\
\hline \multirow[t]{4}{*}{04.100} & 1 & 85 & 7.11 & 0.19 & 19.7 & & 85 & 8.23 & 0.39 & 5.4 & \\
\hline & 3 & 50 & 5.22 & 2.01 & 57.5 & 12.1 & 55 & 6.45 & 0.91 & 15.6 & 4.0 \\
\hline & 5 & 10 & 4.73 & 2.64 & 50.2 & 20.4 & 30 & 5.54 & 1.20 & 19.8 & 15.3 \\
\hline & 7 & 0 & 4.55 & 2.69 & 33.3 & & 25 & 5.02 & 1.26 & 11.7 & 16.4 \\
\hline \multirow[t]{4}{*}{04.101} & 1 & 80 & 8.10 & 0.18 & & & 90 & 7.03 & 0.02 & & \\
\hline & 3 & 65 & 6.23 & 1.14 & 6.6 & & 80 & 5.22 & 0.62 & & \\
\hline & 5 & 60 & 6.01 & 1.89 & 26.3 & 8.3 & 75 & 4.31 & 0.93 & 12.6 & \\
\hline & 7 & 25 & 4.24 & 1.90 & 18.4 & 10.1 & 75 & 3.95 & 0.93 & 8.4 & \\
\hline
\end{tabular}

Fungal incubation in $\mathrm{LCM}$ at $30^{\circ} \mathrm{C}$ and $150 \mathrm{rpm}$ per 7 days 
dye concentration and the increasing of the biomass concentration occurred with non-significant amounts of dye adsorbed by the fungal cell walls, which was confirmed using an autoclaved biomass as controls.

Different patterns of decolourisation and biomass increase shown in Table 3 were assigned to the enzyme system of the fungal strains used. In order to clarify these biochemical processes, the enzyme activities during each assay were assessed for both dyes. For RB5, the high decrease in dye concentration percentages presented by MUM 94.04, 04.100 and 04.101 was believed to be due to the presence of high Lcc concentration in the LCM assays. Additionally, the degradation of this dye can be also due to the presence of LiP and GLOX. These two enzymes should present an integrative mechanism in order to create a degradative enzyme complex with Lcc.

The decrease of $\mathrm{pH}$ during decolourisation of RB5 and PR478 by the strains selected was observed (Table 3 ). These microorganisms have the capacity to change the medium $\mathrm{pH}$ producing organic acid and consequently providing best conditions for development (Neto et al. 2011).

For RB5 (Table 3), the maximum Lcc and LiP activities were found for MUM 04.100 at pH9.5. Under these conditions, Lcc was found with the following values: $19.7 \mathrm{U} / \mathrm{L}$ at day $1 ; 57.5 \mathrm{U} / \mathrm{L}$ at day $3 ; 50.2 \mathrm{U} / \mathrm{L}$ at day 5 and $33.3 \mathrm{U} / \mathrm{L}$ at day 7, and LiP activity was detected as follows: $12.1 \mathrm{U} / \mathrm{L}$ at day 3 and 20.4 U/L at day 5. High level of Lcc was also detected for MUM 94.04: 9.4 U/L by day $1 ; 42.1 \mathrm{U} / \mathrm{L}$ at day $3 ; 47.3 \mathrm{U} / \mathrm{L}$ at day 5 and $27.5 \mathrm{U} / \mathrm{L}$ at day 7 . For this strain, LiP activity was detected with the following values: $5.3 \mathrm{U} / \mathrm{L}$ at day $3,8.4 \mathrm{U} / \mathrm{L}$ at day 5 and $4.2 \mathrm{U} / \mathrm{L}$ at day7. Residual GLOX activities were found for both these strains. Furthermore, MnP and protease activities were not detected in either strain.

In contrast, using the methodologies here presented, Lcc was not detected during the assays involving strain MUM 94.15. However, during the current studies, this strain was capable of decolourising RB5 at a comparable decolourisation level to MUM 04.101. Among all known lignolytic fungi, $P$. chrysosporium is considered to be a WRF model (Lucas et al. 2008). In the 1980s, P. chrysosporium was described as a fungal species capable of producing the two extracellular enzymes LiP and MnP (Noreen et al. 2011). These enzymes have been demonstrated to be the major components of the lignin degradation system of this organism (Mohammadi and Nasernejad 2009). However, in the present study, the decolourisation of RB5 dye described by P. chrysosporium strain MUM 94.15 can be assigned to two enzymes, LiP and GLOX.

For PR478 assays (Table 3), the highest enzyme activities were found for MUM 94.04 and 04.100 , respectively, at $\mathrm{pH}$ 8.5. Under these conditions, for MUM 94.04, the enzyme activities were found with the following values: $20.1 \mathrm{U} / \mathrm{L}$ at day $3 ; 30.3 \mathrm{U} / \mathrm{L}$ at day 5 and $26.5 \mathrm{U} / \mathrm{L}$ at day 7 for Lcc and $6.3 \mathrm{U} / \mathrm{L}$ at day $3,13.3 \mathrm{U} / \mathrm{L}$ at day 5 and $20.2 \mathrm{U} / \mathrm{L}$ at day 7 for
LiP. For this strain, GLOX presented residual activity on days 3 and 5. On the other hand, for MUM 04.100, the enzyme activities found were: $5.4 \mathrm{U} / \mathrm{L}$ on day $1 ; 15.6 \mathrm{U} / \mathrm{L}$ at day $3 ; 19.8 \mathrm{U} / \mathrm{L}$ at day 5 and $11.7 \mathrm{U} / \mathrm{L}$ at day 7 for Lcc and $4.0 \mathrm{U} / \mathrm{L}$ at day $3 ; 15.3 \mathrm{U} / \mathrm{L}$ at day 5 and $16.4 \mathrm{U} / \mathrm{L}$ at day 7 , for LiP. When carrying out the enzyme assays for MUM 94.15, Lcc activity was not detected. However, among the other strains studied, MUM 94.15 presented a high biomass growth with LiP activities comparable to those of MUM 94.04 and 04.100. During the assays GLOX presented residual activity for MUM 94.04 and 94.15. This enzyme was not detected for MUM 04.100 and 04.101. Since MnP under optimal conditions is detected and plays a major role in this system, further investigation is required to clarify the alkaline effect on the MnP expression level.

\section{Conclusions}

Differences were observed in the ability of the 12 fungal strains to decolourise the textile dyes RB5 and PR478 under alkaline conditions. All fungal strains studied presented major abilities to degrade RB5 rather than PR478. T. versicolor MUM 94.04 and 04.100 showed the best degradative capability for both dyes. For these two strains, Lcc activities had the highest detected values during the assays performed for RB5 at pH9.5 and for PR478 at pH8.5. It also can be extrapolated for use in textile effluent environments.

\section{References}

Anastasi A, Spina F, Prigione V, Tigini V, Giansanti P, Varese GC (2010) Scale-up of a bioprocess for textile wastewater treatment using Bjerkandera adusta. Bioresource Technol 101:3067-3075

Anastasi A, Parato B, Spina F, Tigini V, Prigione V, Varese GC (2011) Decolourisation and detoxification in the fungal treatment of textile wastewaters from dyeing processes. New Biotechnol 29:38-45

Aravind UK, George B, Baburaj MS, Thomas S, Thomas AP, Aravindakumar CT (2010) Treatment of industrial effluents using polyelectrolyte membranes. Desalination 252:27-32

Asgher M, Azim N, Bhatti HN (2009) Decolorization of practical textile industry effluents by white rot fungus Coriolus versicolor IBL-04. Biochem Eng J 47:61-65

Barrasa JM, Martínez AT, Martínez MJ (2009) Isolation and selection of novel basidiomycetes for decolorization of recalcitrant dyes. Folia Microbiol 54:59-66

Enayatzamir K, Tabandeh F, Yakhchali B, Alikhani HA, Couto SR (2009) Assessment of the joint effect of laccase and cellobiose dehydrogenase on the decolouration of different synthetic dyes. J Hazard Mater 169:176-181

Faraco V, Pezzella C, Miele A, Giardina P, Sannia G (2009) Bioremediation of colored industrial wastewaters by the white-rot fungi Phanerochaete chrysosporium and Pleurotus ostreatus and their enzymes. Biodegradation 20:209-220

Kalpana D, Shim JH, Oh B-T, Senthil K, Lee YS (2011) Bioremediation of the heavy metal complex dye Isolan Dark Blue 2SGL-01 by white rot fungus Irpex lacteus. J Hazard Mater 98:198-205 
Kaushik P, Malik A (2009) Fungal dye decolorization: recent advances and future potential. Environ Int 35:127-141

Lucas M, Mertens V, Corbisier A-M, Vanhulle S (2008) Synthetic dyes decolourisation by white-rot fungi: development of original microtitre plate method and screening. Enzym Microb Tech 42:97-106

Maalej-Kammoun M, Zouari-Mechichi H, Belbahri L, Woodward S, Mechichi T (2009) Malachite green decolourization and detoxification by the laccase from a newly isolated strain of Trametes sp. Int Biodeter Biodegr 63:600-606

Martins MAM, Lima N, Silvestre AJD, Queiroz MJ (2003) Comparative studies of fungal degradation of single or mixed bioaccessible reactive azo dyes. Chemosphere 52:967-973

Mechichi T, Mhiri N, Sayadi S (2006) Remazol Brilliant Blue R decolourization by the laccase from Trametes trogii. Chemosphere 64:998-1005

Moya R, Hernández M, García-Martín AB, Ball AS, Arias ME (2010) Contributions to a better comprehension of redox-mediated decolouration and detoxification of azo dyes by a laccase produced by Streptomyces cyaneus CECT 3335. Bioresour Technol 101:22242229

Mohammadi A, Nasernejad B (2009) Enzymatic degradation of anthracene by the white rot fungus Phanerochaete chrysosporium immobilized on sugarcane bagasse. J Hazard Mater 161:534-537

Neto SLM, Esteves PJ, Santos VTO, Paranhos AP, Cescato F, Vitali VM, Machado KMG (2011) Novel salt and alkali tolerant neotropical basidiomycetes for dye decolorisation in simulated textile effluent. World J Microbiol Biotechnol 27:2665-2673

Noreen R, Asgher M, Bhatti HN, Batool S, Asad MJ (2011) Phanerochaete chrysosporium IBL-03 secretes high titers of manganese peroxidase during decolorization of Drimarine Blue K2RL textile dye. Environ Technol 32:1239-1246

Novotný C, Dias N, Kapanen A, Malachová K, Vándrovcová M, Itävaara M, Lima N (2006) Comparative use of bacterial, algal and protozoan tests to study toxicity of azo- and anthraquinone dyes. Chemosphere 63:1436-1442

Prigione V, Tigini V, Pezzella C, Anastasi A, Sannia G, Varese GC (2008) Decolourisation and detoxification of textile effluents by fungal biosorption. Water Res 42:2911-2920

Ramya M, Anusha B, Kalavathy S, Devilaksmi S (2007) Biodecolorization and biodegradation of reactive blue by Aspergillus sp. Afr J Biotechnol 6:1441-1445

Reid R (1996) Go green - a sound business decision. J Soc Dyers Color 112:103-105

Revankar MS, Lele SS (2007) Synthetic dye decolorization by white rot fungus, Ganoderma sp. WR-1. Bioresource Technol 98:775-780

Rigas F, Dritsa V (2006) Decolourisation of a polymeric dye by selected fungal strains in liquid cultures. Enzym Microb Tech 39:120-124

Sukumar M, Sivasamy A, Swaminathan G (2009) In situ biodecolorization kinetics of Acid Red 66 in aqueous solutions by Trametes versicolor. J Hazard Mater 167:660-663

Toh Y-C, Jia J, Yen L, Obbard JP, Ting Y-P (2003) Decolourisation of azo dyes by white-rot fungi (WRF) isolated in Singapore. Enzym Microb Tech 33:569-575

Yesilada O, Yildirim SC, Birhanli E, Apohan E, Asma D, Kuru F (2010) The evaluation of pre-grown mycelial pellets in decolorization of textile dyes during repeated batch process. World $\mathrm{J}$ Microb Biot 26:33-39 